\title{
Government Spending, Distortionary Taxation and the International Transmission of Business Cycles
}

\author{
María Pía Olivero \\ Drexel University
}

\begin{abstract}
We study the international transmission of aggregate TFP shocks by introducing demand-side shocks to government spending into an otherwise standard DSGE two-country, two-good model. In the model the substitutability in consumption between private and public goods works to limit international risk sharing. Further, the distortive taxation used to finance the provision of public goods works to increase the correlation of employment, investment and output across countries relative to standard models that lack this friction. In the quantitative analysis we can bring the predictions of the theory closer to the observed properties of the data on the comovement of macroeconomic variables between the United States and other OECD countries. We are also able to provide a potential explanation to some of the puzzles in the international RBC literature, as identified by Backus, Kehoe and Kydland (1992). The topic we study is fundamentally relevant and timely at a time when the crisis in the United States has spread to several other countries in the developed world, forcing governments to engage in active fiscal policy to help their economies in recession.
\end{abstract}

- JEL Classification: F41, F42

- Key Words: International RBC, Fiscal Policy, Demand-side Shocks

\footnotetext{
*Corresponding address: María Pía Olivero; Department of Economics, LeBow College of Business, Drexel University, Matheson Hall, suite 503-A, 3141 Chestnut Street, Philadelphia, PA 19104, USA, Tel: (215) 895-4908, e-mail: maria.olivero@drexel.edu.

(C)2010-Center for International Economics, Sejong Institution, Sejong University, All Rights Reserved.
} 


\section{Introduction}

In this paper we study the international transmission of business cycles by introducing demand-side shocks to government spending into an otherwise standard DSGE two-country, two-good model. A novel aspect of our paper is that it incorporates demand-side shocks as a way to explain the transmission of business cycles. Conversely, most of the existing work on this literature relies exclusively on supply-side shocks.

The inclusion of government spending financed through distortionary taxes on labor income generates the main mechanism for the international transmission of aggregate shocks at the core of our model. This makes the topic particularly interesting at a time when the crisis in the United States has spread to the rest of the developed world, and has forced significant increases in public spending to fight the world recession.

The framework we develop allows us to address three major discrepancies between the observed properties of the data and what standard models predict regarding the international cyclical co-movement of consumption, employment, investment and output. These discrepancies were first identified by Backus, Kehoe and Kydland (1992 and 1994, hereafter BKK) for the OECD countries, and they have been a recurrent subject within the international RBC literature since then. The "quantity anomaly" or "consumption / output / productivity anomaly" is related to the fact that while in the data correlations of output across countries are larger than analogous correlations for consumption, previous theoretical work consistently obtains consumption cross-country correlations that significantly exceed output correlations. Also, while in the data investment and employment tend to co-move across countries, the vast majority of previous work predicts a negative cross-country correlation ${ }^{12}$ (see Table 1 for the cross-country correlations for consumption, output, employment and investment between the United States and other OECD countries). Last, the "price variability anomaly" relates to the fact that the volatility of the terms of trade relative to that of output is significantly larger in the data than what is predicted by the existing theoretical literature.

${ }^{1}$ In models where agents are assumed to have access to a complete set of state-contingent claims, there is perfect international risk-sharing, and consumption levels are perfectly correlated across countries. Also, with no exogenous restrictions to capital mobility, capital flows from the rest of the world into the country where productivity is relatively higher. This gives rise to the negative cross-country correlations of factors of production, and to the very low cross-country output correlations, driven mainly by the exogenous spillovers in total factor productivity. 
After BKK, the work on international RBC has been very productive and has allowed us to gain a better understanding of the channels for the international transmission of business cycles. ${ }^{3}$ Tables A-1 and A-2 in the appendix summarize the results of this literature. Despite all this work it is evident from these tables that the anomalies still present a puzzle for the literature.

We develop a DSGE two-country, two-good model. In the model there is trade in both consumption and investment goods, agents derive utility from the consumption of public goods financed with distortionary taxes on labor income, and financial markets are incomplete.

The fact that agents derive utility from the consumption of public goods as well as from private consumption hinders international risk-sharing, lowering the comovement of consumption across countries. This feature of the model also works to get increased co-movement of output levels. The intuition is the following: Output, tax revenues and government spending all increase after an economy is shocked with an increase in total factor productivity. The marginal utility of consumption falls (by private and public expenditure acting as substitutes in the utility function), making labor supply shrink. This helps to get a reduced impact of the technological shock in the benefited country. Also, a positive aggregate TFP shock in the domestic economy is transmitted to the foreign country because the domestic fiscal expansion endogenously raises the world interest rate, which induces foreign labor supply and output to increase. This implies an increased

\footnotetext{
${ }^{2}$ Table A-1 summarizes the results of some studies that were successful at replicating the cross-country comovement of both investment and employment. One of these studies is Canova and Ubide (1997) who introduce household goods to explain the anomalies. However, with no international trade in differentiated goods, their model cannot deal with the terms of trade anomaly together with the consumption and comovement anomalies. Another of these studies is Hairault (2002) who modifies the traditional modeling of the labor market in the two-country real business cycle model. After the economies are shocked, expected returns to labor market search change and induce movements in search and recruiting activities. The stock of employment changes as a result and the effects of the shocks are propagated through time. Employment movements help to partially curtail the capital outflows from the country which does not benefit from the shock. However, still with no international trade in differentiated goods he cannot address the terms of trade variability anomaly. Cook (2002) develops an imperfectly competitive dynamic model where the shock to one economy spills to the other through demand channels and induces additional business formation in the other economy Markups decline and employment, investment and production increase in both economies. International comovement is obtained only for a particular modeling of the entry game. Finally, Heathcote and Perri (2002) is a model of financial autarky where risk sharing is completely prohibited.

${ }^{3}$ The most important features that have been studied aiming to provide an explanation for these anomalies are the inclusion of non-traded goods, the introduction of price or wage rigidities in monetary models, and the modeling of credit market incompleteness and imperfect competition in goods markets.
} 
cross-country correlation for employment and, by factor complementarity in the production function, an increased cross-country correlation for investment. ${ }^{4}$

Also, developing a two-good model allows us to study the issue of the volatility of the terms of trade and to address the "price variability" anomaly. In the model each country completely specializes in the production of one of the goods, which are imperfect substitutes in consumption for households and in investment for firms. This generates a "demand channel": when one of the countries is hit by a positive TFP shock, its wealth increases and it raises its demand for foreign goods, so that some of the benefits spill over abroad. Also, the change in relative supply of the two goods (generated by the exogenous TFP shock) generates a "terms of trade channel". The country for which terms of trade improve receives a positive wealth effect. Both the "demand channel" and the "terms of trade channel" are part of the overall "trade channel". To model these features of our economy we build on the results by Baxter and Kouparitsas (2005), who empirically show that bilateral trade is a robust variable in explaining international co-movements.

Closely related to our work is Roche (1996) where agents also derive welfare from the consumption of public goods. There are three important differences with our work. First, in Roche (1996) government spending is financed through lumpsum taxes. Second, his is a one-good model. Third, perfect risk sharing across countries is possible in his model since households are assumed to have access to a complete set of state-contingent claims. Therefore, his model is not suitable to study the co-movement of factors of production or the "price-variability" anomaly (see Table A-1 for a summary of Roche's results). Also related to our work are Stockman and Tesar (1998) and Heathcote and Perri (2002) who study the role of trade in two differentiated goods for the international transmission of business

\footnotetext{
${ }^{4}$ It is important to highlight that even though throughout the paper we always refer to government spending, the model actually deals only with the consumption share of overall government spending, ignoring government investment. We justify this modeling choice since we want to follow the standard in the international real business cycle literature in which models with a government sector always focus only on public consumption (Baxter, 1995; Roche, 1996; Kollman, 1998; and Kollman, 2010 among others). Modeling government investment in a meaningful way is beyond the scope of this literature in general and of our paper in particular because it would imply introducing additional frictions on the supply side of the model that would work in a way similar to investment frictions in the private sector. Specifically, the positive productivity shock in one country would drive an increase in both private and public investment in this case. In a model with free capital mobility, this would imply even stronger outflows of capital from the other economy and even larger negative cross-country co-movements of factors of production and output than in standard models without government investment. Conversely, it is our goal in this paper to study frictions on the demand side by focusing on shocks to government consumption.
} 
cycles.

On the empirical side, the role played by government budget deficit shocks in the international transmission of business cycles has been studied by Darvas et al (2005). They find that countries with more similar government budget positions (in the form of persistently similar ratios of government surplus/deficit to GDP) tend to have business cycles that fluctuate more closely, and that reduced fiscal deficits increase business cycle synchronization. ${ }^{5}$

Following this introduction the structure of the paper is as follows. The model is presented in Section II and solved analytically in Section III. Section IV contains the results from the numerical simulations of our benchmark model as well as for some robustness checks. Section V concludes. An appendix summarizes the results of previous work on this literature.

\section{The Model}

In this section we extend the standard two-country model in the international $\mathrm{RBC}$ literature to include trade in two imperfectly substitutable goods and a government sector.

Each economy (home and foreign) is comprised of a representative consumer, a representative firm and a government sector. Firms in each country use countryspecific labor and capital to produce goods operating a constant returns to scale technology. Each country completely specializes in the production of one of the goods.

Here we present the optimization problem for agents in the home country. By symmetry, analogous problems apply to the foreign country. An asterisk is used to denote foreign country variables.

\section{A. The Household Sector}

Households choose consumption of domestic and imported goods $\left(x_{1}\right.$ and $x_{2}$, respectively), labor $\left(L_{t}\right)$ and international asset holdings $\left(\Gamma_{t+1}\right)$ to maximize the expected present discounted value of lifetime utility. Thus, the only way in which households are allowed to smooth consumption is by accessing the market for riskfree bonds. These are in zero-net supply and denominated in units of domestic

${ }^{5}$ On a related topic but dealing with domestic instead of international real business cycles, Furceri (2009) finds that countries with similar government budget positions (in the form of persistently similar ratios of government surplus/deficit to GDP) tend to have smoother business cycles and grow faster. 
consumption. ${ }^{6}$

The representative household's optimization problem is given by:

$$
\begin{gathered}
\operatorname{Max} E_{0} \sum_{t=0}^{\infty} \tilde{\beta}_{t} U\left(C_{t}, L_{t}, G_{t}\right) \\
\text { s.t. } C_{t}=\left[\xi_{C} x_{1 t}^{\rho C}+\left(1-\xi_{C}\right) x_{2 t}^{\rho C}\right]^{1 / \rho C} \\
x_{1 t}+T_{t} x_{2 t}+p_{t}^{C} \Gamma_{t+1}=p_{t}^{C} \Gamma_{t}\left(1+r_{t}^{W}\right)+w_{t} L_{t}(1-\tau)+\pi_{t} \\
\lim \frac{\Gamma_{t}}{\prod_{\tau=0}^{t}\left(1+r_{\tau}^{W}\right)} \geq 0 \\
t \rightarrow \infty
\end{gathered}
$$

Households derive welfare from the consumption of both private and public goods, so that welfare is given by $U(C, L, G)$. Equation (1) introduces the domestic consumption aggregate $C$ over goods produced in the home and the foreign country ( $x_{1}$ and $x_{2}$, respectively), where $\rho^{C}<1$, and $\frac{1}{\left(1-\rho^{C}\right)}$ denotes the elasticity of substitution between domestic and foreign goods. ${ }^{7}$ Equation (2) is the budget constraint of the representative household. It states that spending on consumption goods plus purchases of assets have to equal total income given by asset income, after-tax labor income and domestic firm profits (rebated to households in a lumpsum fashion). In this equation $T$ denotes the terms of trade defined as the price of foreign goods relative to domestic goods, ${ }^{8} p^{C}$ is the price of local consumption, $r^{W}$ denotes the world interest rate, $w$ is the nominal wage rate, $\tau$ is the income tax rate, and $\pi$ are local firms profits. Last, equation (3) is the standard transversality

\footnotetext{
${ }^{6}$ It is well accepted in this literature that incomplete financial markets deliver decreased consumption correlations across countries. With imperfect risk-sharing, marginal rates of substitution are equalized across countries only in expected value, not for all periods and states of the world. Also, with incomplete markets, the positive wealth effect of a productivity shock in the home country makes domestic agents reduce the number of hours they work, which works to raise the implied cross-country co-movement of employment and output. Nevertheless, it has been shown that the anomalies persist even when households are completely banned from intertemporal trade in assets, which suggests that they do not arise simply from the assumption of complete asset markets (see Backus, Kehoe and Kydland (1992) and Heathcote and Perri (2002) for details).

${ }^{7}$ This functional form for the $\mathrm{C}$ aggregate is general enough to allow for the cases of perfect substitutability and perfect complementarity between domestic and foreign goods. Also, the elasticity of substitution in consumption is allowed to differ from the elasticity in investment.

${ }^{8}$ This definition is used to make terms of trade comparable to the macroeconomic concept of the real exchange rate.
} 
condition introduced to rule out Ponzi schemes in households borrowing.

It is clear from this optimization problem that households use an endogenous and time-varying discount factor $\tilde{\beta}_{t}$. In Section IV we expand the presentation of this endogenous discount factor and discuss why it is needed in this class of models.

\section{B. The Production Sector}

A representative firm in each economy chooses employment $\left(L_{t}\right)$, investment and the capital stock $\left(I_{t}\right.$ and $\left.K_{t+1}\right)$ and the allocation of total investment among domestic and foreign goods ( $l_{1}$ and $t_{2}$, respectively) to maximize expected lifetime profits. Thus, the firm's optimization problem is given by:

$$
\begin{gathered}
\operatorname{Max} \sum_{t=0}^{\infty}\left(1+r_{t}^{W}\right)^{-t} \pi_{t} \\
\pi_{t}=Y_{t}-w_{t} L_{t}-p_{t}^{I} I_{t} \\
K_{t+1}=I_{t}+(1-\delta) K_{t} \\
Y_{t}=F(z, K, L)=z_{t} K_{t}^{\alpha} L_{t}^{(1-\alpha)} \\
\mathbf{A}_{\mathrm{t}+1}=\lambda \mathbf{A}_{t}+\varepsilon_{\mathrm{t}+1} \quad \mathbf{A}_{\mathrm{t}} \equiv\left(z_{t}, z_{t}^{*}\right) \quad \boldsymbol{\varepsilon}_{t} \equiv\left(\varepsilon_{\mathrm{t}}, \varepsilon_{\mathrm{t}}^{*}\right) \\
I_{t}=\left[\xi_{I} \iota_{1 t}^{\rho I}+\left(1-\xi_{I}\right){ }_{2 t}^{\rho I}\right]^{I / \rho I}
\end{gathered}
$$

Equation (5) is the standard law of motion for the capital stock in the economy. Equation (6) is the constant returns to scale Cobb-Douglas production technology in each country. Equation (7) is the AR(1) process followed by exogenous TFP. The elements of $\varepsilon_{\mathrm{t}}$ are serially independent, multivariate, normal random variables with contemporaneous covariance matrix $\boldsymbol{V}$. Productivity is stochastically related across countries through the off-diagonal elements of both $\lambda$ and $\boldsymbol{V}$, which define the TFP spillovers from one country to the other. Last, equation (8) defines total investment as a CES aggregate of local and imported capital goods.

\section{The Government Sector}

The government in each country spends on goods and services $(G)$, taxes labor income at a rate $\tau$ and collects lump-sum taxes $(V)$. Thus, the government budget 
constraint is given by:

$$
G_{t}=V_{t}+\tau w_{t} L_{t}
$$

This equation implicitly assumes that the government has to balance its budget in each and every period. Admittedly, this is a simplification that makes the model lose in terms of realism. Allowing for intertemporal effects derived from the government being able to issue bonds to finance government spending is beyond the scope of the current paper, and left as an extension for future work.

Government spending follows an $\mathrm{AR}(1)$ process of the form: ${ }^{9}$

$$
G_{t}=\kappa G_{t-1}+\eta_{t} \quad \eta_{t} \sim N\left(0, \sigma_{\eta}^{2}\right)
$$

Government spending is modeled as entirely exogenous in our setup. Endogenizing government spending decisions such that government consumption would respond to the aggregate state of the economy (making $\mathrm{G}$ a function of the output gap, for example) is beyond the scope of our paper. Our goal is to address the question of how fiscal policy shocks can play a role in the international transmission of business cycles, independently from the reason why government spending is shocked. This modeling choice is consistent with the vast majority of the literature on fiscal policy that looks at the effects on various macroeconomic variables of exogenous shocks to public consumption.

In Section IV we present the details on the calibration of the process followed by government spending.

\section{The Economy's Equilibrium}

The recursive competitive equilibrium in this economy is defined by value functions $\mathrm{V}^{\mathrm{H}}(\mathrm{A}, \Gamma)$ for the home household and $\mathrm{V}^{\mathrm{H}}\left(\mathrm{A}, \Gamma^{*}\right)$ for the foreign household, $\mathrm{V}^{\mathrm{F}}(\mathrm{A}, \mathrm{K})$ for the home firm and $\mathrm{V}^{\mathrm{F}}\left(\mathrm{A}, \mathrm{K}^{*}\right)$ for the foreign firm, ${ }^{10}$ decision rules on consumption of domestic and foreign goods, employment and asset holdings for both households, decision rules on employment and investment

\footnotetext{
${ }^{9} \mathrm{We}$ model government spending as an auto-regressive process of order 1 . In doing so, we follow the standard convention in the real business cycles literature to model all types of exogenous shocks. Actually, other types of exogenous processes for $G$ would invalidate our numerical solution method of log-linearizing the set of equilibrium conditions around the deterministic steady-state.

${ }^{10}$ The superscript $\mathrm{H}$ stands for households, and $\mathrm{F}$ for firms.
} 
for the home firm and the foreign firm and prices $\left(p^{C}, p^{I}, w, w^{*}, T, r^{W}\right)$ that satisfy the following conditions:

- The home and foreign households' FOCs;

- the home and foreign firms' FOCs;

- the world resource constraints for both goods; and

- the market clearing conditions for the labor, capital and asset markets.

\section{Model's Solution}

From the FOCs for the representative household we obtain equations (11)-(14).

The Euler equation for consumption which governs the optimal intertemporal allocation of aggregate consumption is:

$$
\frac{U_{C_{t}}^{\prime}}{p_{t}^{c}}=\beta E_{t}\left[\frac{U_{C_{t+1}}^{\prime}}{p_{t+1}^{c}}\left(1+r_{t+1}^{W}\right)\right]
$$

The price of domestic consumption $p^{C}$ in terms of the domestic good (the numeraire) is:

$$
p_{t}^{c}=\left[\xi_{C}+\left(1-\xi_{C}\right) T_{t}^{\rho C /(\rho C-1)}\right]^{(\rho C-1) / \rho C}
$$

The intratemporal condition for the allocation of consumption between domestic and imported goods is given by:

$$
\frac{\xi_{C}}{\left(1-\xi_{C}\right)}\left(\frac{x_{1 t}}{x_{2}}\right)^{\rho C-1}=\frac{1}{T_{t}}
$$

Equation (14) determines household labor-leisure choices. The fact that $\mathrm{f}\left(G_{t}\right)<0$ shows that government spending imposes negative wealth effects on labor supply by lowering the marginal utility of consumption. Simultaneously, taxes on labor income used to finance government purchases lower the after-tax wage rate and exert a substitution effect on labor.

$$
\omega L_{t}^{\omega-1}=\frac{w_{t}(1-\tau)}{p_{t}^{C}} f\left(G_{t}\right)
$$

From the FOCs for the representative firm we obtain equations (15)-(18).

The allocation of investment between domestic and foreign goods is governed by equation (15). 


$$
\frac{\xi_{I}}{\left(1-\xi_{I}\right)}\left(\frac{l_{1 t}}{l_{2}}\right)^{\rho I-1}=\frac{1}{T_{t}}
$$

The price of the domestic investment in terms of domestic output is given by equation (16).

$$
p_{t}^{I}=\left[\xi_{I}+\left(1-\xi_{I}\right) T_{t}^{\rho I /(\rho I-1)}\right]^{(\rho I-1) / \rho I}
$$

Equation (17) is the standard inverse labor demand function for the local firm.

$$
w_{t}=(1-\alpha) z_{t} K_{t}^{\alpha} L_{t}^{-\alpha}
$$

Finally, equation (18) is the intertemporal condition governing investment decisions by the firm.

$$
\frac{1}{\left(1+r_{t}^{W}\right)} E_{t}\left\{\frac{\partial Y_{t+1}}{\partial K_{t+1}}+p_{t+1}^{I}(1-\delta)\right\}=p_{t}^{I}
$$

\section{A. Market Clearing}

World output of each good is devoted to private and public consumption and investment. Thus, the market clearing conditions in goods markets are:

$$
\begin{aligned}
& x_{1 t}+x_{1 t}^{*}+\imath_{1 t}+\imath_{1 t}^{*}+G_{t}=z_{t} F\left(K_{t}, L_{t}\right) \\
& x_{2 t}+x_{2 t}^{*}+\imath_{2 t}+\imath_{2 t}^{*}+G_{t}^{*}=z_{t}^{*} F\left(K_{t}^{*}, L_{t}^{*}\right)
\end{aligned}
$$

With international assets in zero net supply, market clearing in asset markets is given by:

$$
\Gamma_{t+1}+\Gamma_{t+1}^{*}=0
$$

\section{Results}

\section{A. The Data}

Cross-country correlations for consumption and output are both positive in the 
Table 1. The Data

\begin{tabular}{lc}
\hline International Comovement & \\
\hline$\rho\left(\mathrm{C}, \mathrm{C}^{*}\right)$ & 0.3311 \\
$\rho\left(\mathrm{Y}, \mathrm{Y}^{*}\right)$ & 0.4496 \\
$\rho\left(\mathrm{I}, \mathrm{I}^{*}\right)$ & 0.4151 \\
$\rho\left(\mathrm{L}, \mathrm{L}^{*}\right)$ & 0.2167 \\
& \\
Cyclicality of the Trade Balance & -0.37 \\
$\rho(\mathrm{NX} / \mathrm{Y}, \mathrm{Y})$ & \\
& \\
Volatility of the Terms of Trade & 3.68 \\
$\sigma \mathrm{T}(\%)$ & \\
\hline
\end{tabular}

Notes: C stands for consumption, L for employment, I for investment and Y for GDP. Correlations between the United States and non-US OECD countries for logged and Hodrick-Prescott filtered quarterly data. The sample period is 1960:I-2002:II. European data refer to the following 15 countries: Austria, Belgium, Denmark, Finland, France, Germany, Greece, Ireland, Italy, Luxembourg, the Netherlands, Portugal, Spain, Sweden and United Kingdom. Data for employment between 1972.1 and 1983.4 is only for the following subgroup: Austria, Finland, France, Germany, Italy, Norway, Spain, Sweden and United Kingdom. Data for employment between 1962.1 and 1971.4 is only for the following subgroup: Finland, Germany, Italy, Sweden and United Kingdom.

Worthy of note is the fact that business cycles in the US have become less correlated with those of the other OECD countries over time. Correlations calculated for the period 1970-1990 by Backus, Kehoe and Kydland (1992) are 0.51 for private consumption, 0.66 for output, 0.53 for investment and 0.33 for employment (see Heathcote and Perri (2003)).

Source: OECD Quarterly National Accounts and OECD Main Economic Indicators for the period 19602002.

data. Consumption are smaller than output correlations. Investment and employment also co-move across countries. Net exports detrended by GDP are countercyclical, and the terms of trade are significantly more volatile than GDP. As discussed in the introduction, standard models cannot typically account for these facts.

Table 1 presents these features of the data that have puzzled the Economics profession for more than a decade now. Thus, one goal of our paper is to assess whether a model with demand-side shocks to government spending, distortionary taxation and trade in goods can help to get the predictions of the theory closer to these observed properties of the data.

\section{B. Calibration}

We follow the usual practice in the $\mathrm{RBC}$ literature, and calibrate the model to match some of the post-war stylized facts for the US and other OECD economies 
Table 2. Calibration

\begin{tabular}{|c|c|}
\hline Utility Function \& Budget Constraint & Consumption Aggregator \\
\hline$\theta=0.3$ & $\varepsilon_{\mathrm{C}}=0.9$ \\
\hline$\theta^{*}=0.1$ & $\rho^{\mathrm{C}}=-1 / 9$ \\
\hline \multicolumn{2}{|l|}{$\omega=1.6$} \\
\hline \multicolumn{2}{|l|}{$\Phi=0.1$} \\
\hline \multicolumn{2}{|l|}{$\sigma=2$} \\
\hline \multicolumn{2}{|l|}{ Production Function } \\
\hline \multicolumn{2}{|l|}{$\alpha=0.36$} \\
\hline Capital Accumulation Process & Investment Aggregator \\
\hline$\delta=0.025$ & $\begin{array}{c}\varepsilon_{\mathrm{I}}=0.9 \\
\rho^{\mathrm{I}}=-1 / 9\end{array}$ \\
\hline \multicolumn{2}{|l|}{ TFP Process (Backus et al) } \\
\hline $\begin{array}{l}\lambda_{11}=\lambda_{22}=0.906 \\
\lambda_{12}=\lambda_{21}=0.088\end{array}$ & $\begin{array}{c}\operatorname{Var}\left(\varepsilon_{\mathrm{t}}\right)=\operatorname{Var}\left(\varepsilon_{\mathrm{t}}^{*}\right)=(0.0085)^{2} \\
\operatorname{Corr}\left(\varepsilon, \varepsilon^{*}\right)=0.25\end{array}$ \\
\hline
\end{tabular}

Note: $*$ denotes foreign country variables.

at the quarterly frequency.

The parameter values for the baseline economy are shown in Table 2 . Simulation results are presented in Table 3.

The distribution of asset holdings between the two countries is not stationary in this economy with incomplete asset markets. Following standard practice in the literature, here we use an endogenous discount factor to make it stationary, where:

$$
\tilde{\beta}_{0}=1 ; \tilde{\beta}_{t+1}=\tilde{\beta}_{t} \psi\left(1+\tilde{C}_{t}-\gamma \frac{\tilde{h}_{t}^{o}}{\omega}\right)^{-\mu} t \geq 0 \text {; and } \tilde{\beta}_{C}<0 \text { and } \tilde{\beta}_{h}<0 \text { Notice that }
$$
the discount factor is typically modeled as a function of average consumption $\left(\tilde{C}_{t}\right)$ and average labor $\left(\tilde{h}_{t}\right)$, which the individual household takes as given. This assumption also implies that the first order conditions of the household's problem are not affected by this feature of the model. In equilibrium, $\tilde{C}_{t}=C_{t}$ and $\tilde{h}_{t}=h_{t}$

In the numerical simulations the parameter $\mu$ is set to the smallest possible value needed to obtain a stationary distribution of assets. The sensitivity of $\tilde{\beta}_{t}$ to consumption and employment is therefore very small, and none of the results are driven by the endogeneity of the discount factor. ${ }^{11}$ The parameter $\psi$ is chosen so that in steady state the discount factor equals the reciprocal of a gross quarterly interest rate of $1 \%$. Bodenstein (2006) shows that in two-country open economy

\footnotetext{
${ }^{11}$ Simulation results are robust to the value of $\mu$, and available from the author upon request.
} 
models endogenous discounting always yields a unique and stable steady state, irrespective of the magnitude of the elasticity of substitution between the domestic and the foreign traded good.

The period utility function is a function of consumption of both private and public goods (which act as substitutes) and leisure. It is given by $U(C, L)=\frac{\left[C G^{\theta}-\Phi L^{\omega} G^{(1+\theta)}\right]^{1-\sigma}}{(1-\sigma)}$ with $(1-\sigma)<1$. These preferences feature a wealth effect on labor supply derived from government purchases. ${ }^{12}$

$\theta$ is chosen to match the steady state ratio of government purchases to output in both economies. $\Phi$ is chosen to guarantee that the marginal utility of both consumption and government purchases is positive and that private and public consumption are substitutes. $\omega$ is calibrated to match the different price elasticities of labor supply in the US and OECD countries. Empirical micro studies for the US labor market including female workers obtain an estimate of around 1.6 for the elasticity of labor supply. ${ }^{13}$ For European countries this elasticity is smaller and closer to one.

The parameters $\xi_{C}$ and $\xi_{I}$ are chosen to match the share of imported goods in total consumption and investment, respectively. Following Heathcote and Perri (2002), the parametersand $\rho^{C}$ and $\rho^{I}$ are chosen to match a 0.9 elasticity of substitution between local and foreign goods in consumption and investment.

In the production function $\alpha$ is calibrated to match a constant output share of capital (labor) equal to $0.36(0.64)$.

The depreciation rate $\delta$ is set to $2.5 \%$ per quarter. To reduce the volatility of international capital flows, we follow the standard practice of assuming that firms have to bear adjustment costs to investment. The per-unit adjustment cost is given by $g\left(K_{t+1}, K_{t}\right)=\phi\left(\frac{K_{t+1}-K_{t}}{K}\right)^{2}$ with the parameter $\phi$ chosen to fix the volatility of investment at five times the volatility of output. ${ }^{14}$

The parameters $\kappa$ and $\sigma_{\eta}$ in the process followed by government spending are calibrated to match the volatility of government spending and the correlation between output and government purchases, respectively. The tax rate on labor income is a free parameter, and we conduct sensitivity analyses on its value (see Table 3).

\footnotetext{
${ }^{12}$ Notice that the fact that the utility function is not separable in leisure reduces cross correlations of consumption below unity, even in a complete markets scenario.

${ }^{13}$ See Heckman (1999).

${ }^{14}$ Notice that this function implies zero adjustment costs in steady state.
} 
Table 3. Simulation Results: Benchmark Model

\begin{tabular}{lcccc}
\hline & $\tau=0.25 \tau^{*}=0.15$ & $\tau=0.35 \tau^{*}=0.15$ & $\tau=0.2 \tau^{*}=0.1$ & $\tau=0.15 \tau^{*}=0.15$ \\
\hline$\rho\left(\mathrm{C}, \mathrm{C}^{*}\right)$ & 0.99 & 0.99 & 0.99 & 0.95 \\
$\rho\left(\mathrm{Y}, \mathrm{Y}^{*}\right)$ & 0.32 & 0.35 & 0.27 & 0.5 \\
$\rho\left(\mathrm{I}, \mathrm{I}^{*}\right)$ & 0.42 & 0.13 & 0.06 & -0.22 \\
$\rho\left(\mathrm{L}, \mathrm{L}^{*}\right)$ & 0.37 & 0.44 & 0.49 & 0 \\
$\rho(\mathrm{NX} / \mathrm{Y}, \mathrm{Y})$ & -0.13 & -0.11 & -0.16 & 0.07 \\
\hline
\end{tabular}

Last, we calibrate the process followed by the total factor productivity following Backus, Kehoe and Kydland (1992). In each economy productivity shocks are highly persistent and spill over to the rest of the world.

\section{Numerical Solution and Results}

The model has no closed form solution and has to be solved using a numerical algorithm. The linearity of the problem and the assumption of moderate shocks allow us to use log-linearization of the system of equilibrium equations around the deterministic steady state to solve the model. In this section we present the results obtained using this methodology.

Table 3 contains the results for our benchmark model, for several alternative values of labor income taxes. It is worth noticing that the parametrizations for which the tax rate in the home country is higher than in the foreign economy are those that reproduce the fact that the GDP share of government spending is higher in the domestic than in foreign country. To avoid clutter we present only the simulation moments that allow us to address the anomalies, namely the crosscountry correlations of macroeconomic aggregates and the cyclicality of the trade balance. Additional simulation results, including domestic business cycle indicators are available from the author upon request.

Our model significantly improves over the results of previous literature in three main ways. First, output is positively correlated for all parametrizations of labor taxes. Second, positive cross-country correlations are also obtained for production inputs, and both investment and employment co-move across countries. Third, we are also able to reproduce the countercyclicality of net exports. Consumption correlations are not significantly reduced relative to a standard model. Consistent with the results obtained by previous work, restricting intertemporal trade to occur only through non-contingent assets does not seem to impose enough restrictions on international risk sharing. However, wealth effects on labor supply allow the crosscountry correlation for consumption to fall below unity. 
Notice the change in results when we parameterize labor income tax rates symmetrically across countries. The reason for this change in results is that when the tax rate in the domestic country is calibrated to be higher than in the foreign country, a fiscal expansion in the domestic economy implies a larger reduction in labor supply there than obtained for a smaller $\tau$. When we parameterize labor income tax rates symmetrically across countries, this negative effect on domestic labor is not strong enough to yield positive cross-country correlations of employment, and we get $\rho\left(\mathrm{L}, \mathrm{L}^{*}\right)=0$. By the complementarity of factors in the production function, this cross-country correlation in employment is not strong enough to yield a high enough correlation in the marginal productivity of capital and hence, in investment.

\section{Impulse Response Functions}

Figure 1 shows the impulse response functions for macroeconomic variables in response to a one standard deviation aggregate shock to TFP in the domestic country. Note that the productivity process is highly persistent. After 30 quarters, productivity has not still returned to its steady state value. It is also evident from Figure 1 that although foreign TFP is not affected on impact, a shock to domestic productivity starts to get transmitted to the rest of the world after one period.

As expected from our discussion on the model's transmission mechanisms, consumption, output, investment and employment all behave similarly in both countries. The dynamic responses for all variables are highly persistent. This can be explained by the high persistence in the TFP process as well as by the small elasticity of the endogenous discount factor. ${ }^{15}$

While financial markets are not complete, some international risk-sharing is allowed through risk-free international bond holdings. In general, both domestic and foreign consumption rise at the period of impact and stay above their steady state levels for several quarters. With agents deriving utility from consumption of both private and public goods, and with government spending increasing in the home country, the increase in consumption in the home country is smaller than abroad.

The computed responses for output in the period of impact are positive in both countries, intuitively less so in the foreign economy. The co-movement for

\footnotetext{
${ }^{15}$ The endogenous rate of time preference eliminates the unit root of the endogenous variables. However, the short run dynamics are similar to those of a model with a constant discount factor (See SchmittGrohe (1998)).
} 
Figure 1. Impulse Response Functions
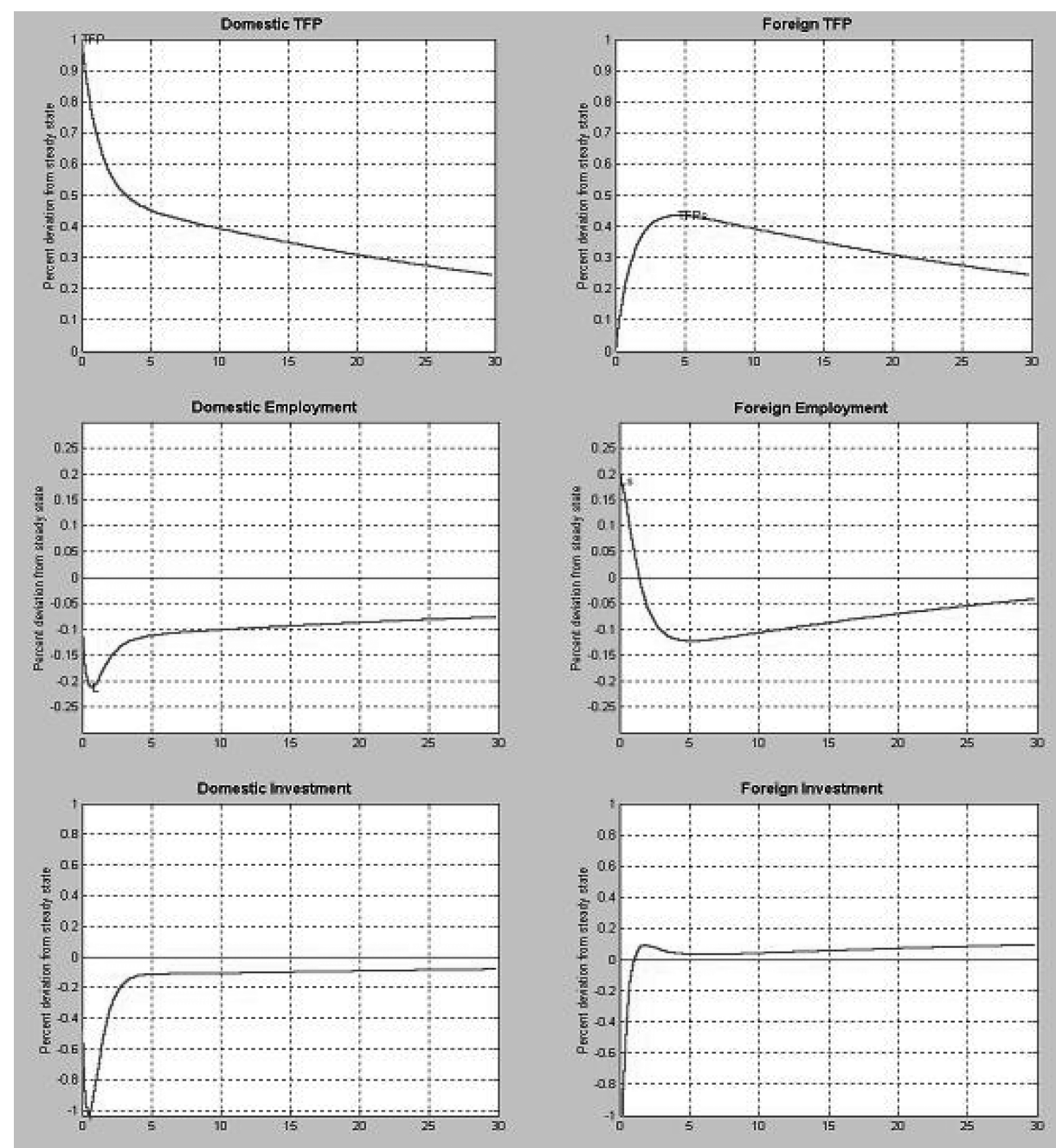

employment and investment implied by the model is evident from the impulse response functions for $L$ and $I$. Only a few quarters after the shock, the capital stock starts increasing in both economies, which raises the demand for labor, and employment and output.

The increase in foreign variables is in part a result of the shock exerting a positive wealth effect on the foreign economy derived from both trade and the behavior of the terms of trade, i.e. from the "demand channel" and the "terms of trade channel". After the shock, home-bias in consumption makes domestic goods relatively more expensive and terms of trade increase, generating a positive 
Figure 1. (ctd.): Impulse Response Functions
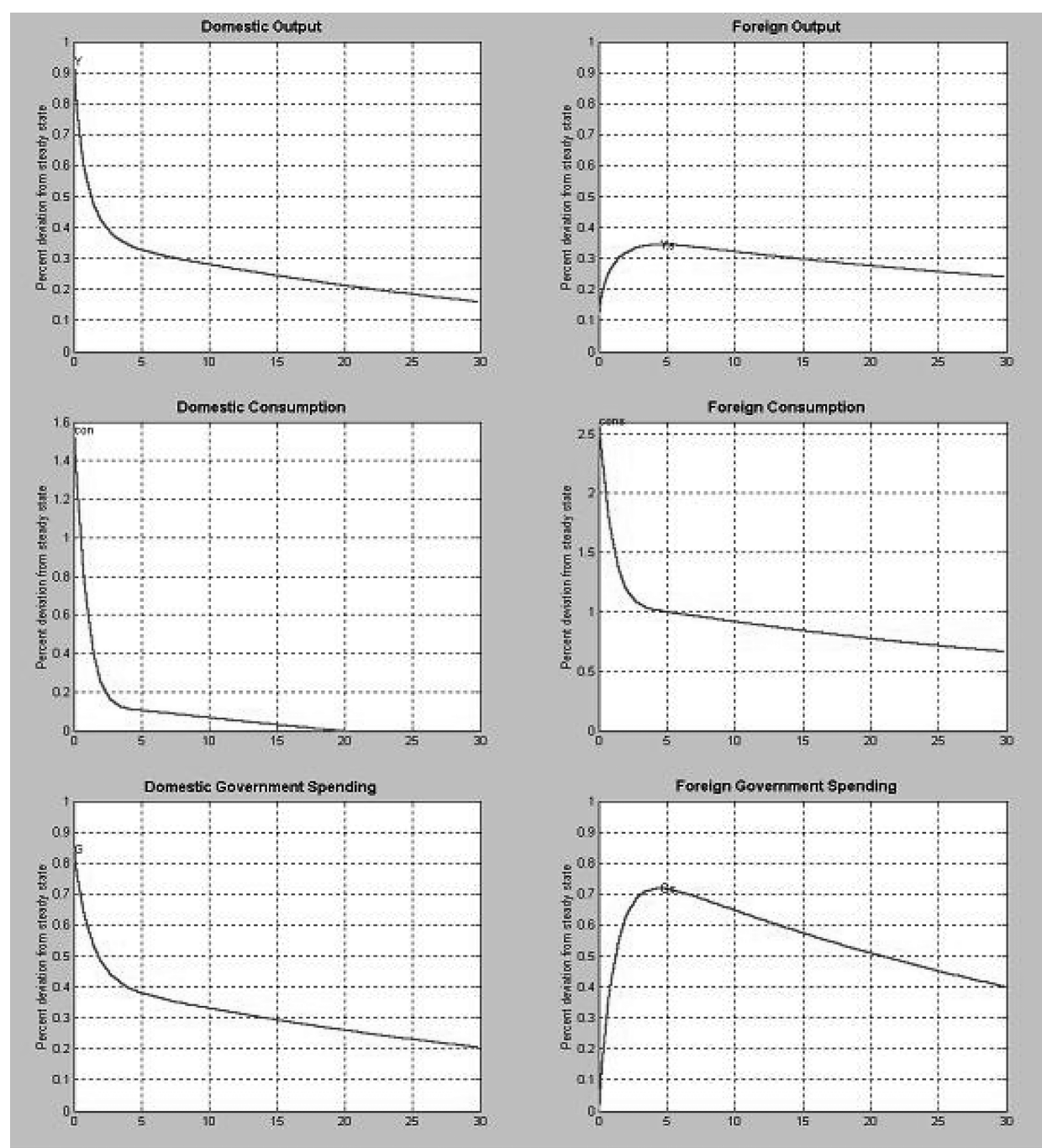

spillover to the foreign economy. ${ }^{16}$

\section{Robustness Checks}

In this section we perform some robustness checks on the baseline model.

Table 4 presents the results for a model with no government sector. In this case investment is negatively correlated across countries and the trade balance is mildly

\footnotetext{
${ }^{16}$ Naturally, the productivity shock makes domestic goods relatively more abundant. While this effect works to lower terms of trade, in the numerical simulations we show that the demand-side effect dominates, and that terms of trade depreciate for the domestic economy.
} 
Table 4. Simulation Results: Model with No Government Sector

\begin{tabular}{cc}
\hline$\rho\left(\mathrm{C}, \mathrm{C}^{*}\right)$ & 0.995 \\
$\rho\left(\mathrm{Y}, \mathrm{Y}^{*}\right)$ & 0.45 \\
$\rho\left(\mathrm{I}, \mathrm{I}^{*}\right)$ & -0.98 \\
$\rho\left(\mathrm{L}, \mathrm{L}^{*}\right)$ & 0.86 \\
$\rho(\mathrm{NX} / \mathrm{Y}, \mathrm{Y})$ & 0.05 \\
\hline
\end{tabular}

Table 5. Simulation Results: Model with No Trade in Goods

$\begin{array}{lc}\rho\left(\mathrm{C}, \mathrm{C}^{*}\right) & 0.93 \\ \rho\left(\mathrm{Y}, \mathrm{Y}^{*}\right) & 0.26 \\ \rho\left(\mathrm{I}, \mathrm{I}^{*}\right) & -0.66 \\ \rho\left(\mathrm{L}, \mathrm{L}^{*}\right) & -0.24 \\ \rho(\mathrm{NX} / \mathrm{Y}, \mathrm{Y}) & -0.05\end{array}$

Table 6. Simulation Results: Model with No Cross-Country Spillovers in TFP

\begin{tabular}{lc}
\hline$\rho\left(\mathrm{C}, \mathrm{C}^{*}\right)$ & 0.99 \\
$\rho\left(\mathrm{Y}, \mathrm{Y}^{*}\right)$ & 0.12 \\
$\rho\left(\mathrm{I}, \mathrm{I}^{*}\right)$ & 0.23 \\
$\rho\left(\mathrm{L}, \mathrm{L}^{*}\right)$ & 0.31 \\
$\rho(\mathrm{NX} / \mathrm{Y}, \mathrm{Y})$ & -0.13 \\
\hline
\end{tabular}

procyclical. These results unveil the importance of demand-side effects derived from procyclical government purchases financed with distortionary taxation. This feature of the model seems crucial to understand the international transmission of business cycles and to explain the anomalies.

Table 5 presents the results for a model with a government sector but without trade in goods. Labor and investment are negatively correlated for this model. Thus, intratemporal trade in consumption and investment is also crucial to explain the anomalies. This result is consistent with the empirical findings in Baxter and Kouparitsas (2005), who empirically show that bilateral trade is a robust variable in explaining the international co-movement of macroeconomic variables.

Table 6 shows the results for a case where aggregate productivity does not spill over across countries. The cross-country correlations for factors of production are still positive in this case. As expected, output correlations fall significantly below the data and below what the benchmark model predicts. Once again, these results highlight the importance of the demand-side mechanisms that we introduce in this paper. Previous work has not been able to provide an explanation to the puzzles even with this alternative parametrization of the TFP process. 
Table 7. Volatility of the Terms of Trade

\begin{tabular}{|c|c|}
\hline & SD tot $(\%)$ \\
\hline US data & 3.68 \\
\hline "Perfect substitutability" Linear $C \rho^{I}=\rho^{C}=0$ & 2.59 \\
\hline "Perfect complements" Leontief C aggregator $\rho^{\mathrm{I}}=\rho^{\mathrm{C}}=1$ & 41.8 \\
\hline Perfect substitutability in $\mathrm{C}$ and perfect complements in I & 2.54 \\
\hline "Intermediate" case $1: \rho^{I}=\rho^{C}=-1 / 8$ & 4.74 \\
\hline "Intermediate" case $2: \rho^{\mathrm{I}}=\rho^{\mathrm{C}}=-1 / 9$ & 2.5 \\
\hline "Intermediate" case $3: \rho^{I}=\rho^{C}=-1 / 10$ & 2.54 \\
\hline "Intermediate" case $4: \rho^{\mathrm{I}}=\rho^{\mathrm{C}}=-1 / 12$ & 2.5 \\
\hline "Intermediate" case $5: \rho^{I}=\rho^{C}=-1 / 15$ & 2.58 \\
\hline "Intermediate" case $6: \rho^{I}=\rho^{C}=-1 / 20$ & 2.53 \\
\hline "Intermediate" case 7: $\rho^{\mathrm{I}}=\rho^{\mathrm{C}}=0.3$ & 1.96 \\
\hline "Intermediate" case 8: $\rho^{\mathrm{I}}=\rho^{\mathrm{C}}=0.4$ & 9.7 \\
\hline "Intermediate" case 9: $\rho^{\mathrm{I}}=\rho^{\mathrm{C}}=0.5$ & 2.76 \\
\hline "Intermediate" case $10: \rho^{\mathrm{I}}=\rho^{\mathrm{C}}=0.6$ & 2.42 \\
\hline "Intermediate" case 11: $\rho^{\mathrm{I}}=\rho^{\mathrm{C}}=0.75$ & 2.34 \\
\hline \multicolumn{2}{|l|}{ High substitutability in C and I } \\
\hline$\rho^{\mathrm{C}}=0.3$ and $\rho^{\mathrm{I}}=0.9$ & 2.68 \\
\hline$\rho^{\mathrm{C}}=0.3$ and $\rho^{\mathrm{I}}=0.95$ & 2.62 \\
\hline$\rho^{\mathrm{C}}=0.5$ and $\rho^{\mathrm{I}}=0.95$ & 2.71 \\
\hline$\rho^{C}=0.5$ and $\rho^{I}=0.97$ & 3.83 \\
\hline
\end{tabular}

Notes: US data is taken from Cooley, "Frontiers of Business Cycle Research", chapter 11.

\section{Terms of Trade and the "Price-Variability" Anomaly}

In this section we explore the behavior of terms of trade in the model, and we study the "price-variability" anomaly. Table 7 shows the results.

The volatility of the terms of trade is significantly increased with respect to standard two-good models. In this case there is both a consumption and an investment aggregate over domestic and foreign goods, and the elasticity of substitution between domestic and foreign goods is allowed to vary between them.

The parametrization where $\rho^{C}=0.5$ and $\rho^{I}=0.97$ most closely matches the volatility of the terms of trade observed in the data. This shows that the degree of substitutability between local and imported goods seems to be higher in investment than in consumption. This seems not far from what one would intuitively expect. 


\section{Concluding Remarks}

In this paper we study the international transmission of business cycles by introducing a government sector that finances its spending through distortionary taxation into an otherwise standard DSGE two-country, two-good model. A novel aspect of our paper is that it incorporates demand-side shocks (originated in both government spending and trade) as a way to explain the transmission of business cycles. Conversely, most of the existing work on this literature focuses on the role of supply-side shocks for this transmission.

In the quantitative analysis we are able to reproduce the positive co-movement for output, investment and employment, the countercyclicality of net exports and the high volatility of the terms of trade in the data. Doing so, we can provide a potential explanation to some of the anomalies identified by BKK.

From these results we conclude that demand-side shocks seem to be important channels through which business cycles are transmitted across countries. Also, the fact that models with no trade in goods and no government purchases cannot provide an explanation to the anomalies unveils the importance of the transmission mechanisms that we study in this paper.

We believe the topic we study in this paper is fundamentally relevant and timely at a time when the crisis in the United States has spread to several other countries in the developed world, forcing governments to engage in active fiscal policy to help their economies in recession.

A natural extension that arises from our results is to study the role for the international transmission of business cycles of additional frictions in credit markets that would further restrict international risk sharing. We leave this for future work.

\section{Acknowledgements}

Special thanks to the editor and an anonymous referee for very productive comments. Roger Aliaga-Díaz, Michelle Connolly, Pietro Peretto, José Wynne and seminar participants at Duke University and Drexel University provided helpful feedback.

Received 30 May 2009, Revised 27 January 2010, Accepted 4 February 2010 


\section{References}

Backus, D., P. Kehoe and F. Kydland (1992), "International Real Business Cycles", Journal of Political Economy, Vol. 100(4), pp. 745-775.

Backus, D., P. Kehoe and F. Kydland (1994), "Dynamics of the Trade Balance and the Terms of Trade: The J-Curve?", American Economic Review, Vol. 84, pp. 84-103.

Baxter, M. (1995), "International Trade and Business Cycles", Chapter 35, Handbook of International Economics, Volume 3, Grossman and Rogoff, (eds).

Baxter, M. and M. Crucini (1995), "Business Cycles and the Asset Structure of Foreign Trade", International Economic Review, Vol. 36(4), November, pp. 821-854.

Baxter, M. and M. Kouparitsas (2005), "Determinants of Business Cycle Comovement: A Robust Analysis", Journal of Monetary Economics, Vol. 52(1), January, pp. 113-57.

Bodenstein, M. (2006), "Closing Open Economy Models", International Finance Discussion Papers 867, Washington: Board of Governors of the Federal Reserve System.

Boileau, M. (1996), "Growth and International Transmission of Business Cycles", International Economic Review, Vol. 37(4), pp. 737-756.

Boileau, M. (2002), "Trade in Capital Goods and Investment-Specific Technical Change", Journal of Economic Dynamics and Control, Vol. 26, pp. 963-984.

Canova, F. and A. Ubide (1998), "International Business Cycles, Financial Markets and Household Production", Journal of Economic Dynamics and Control, Vol. 22, pp. 545-572.

Cole, H. (1988), "Financial Structure and International Trade", International Economic Review, Vol. 29(2), May, pp. 237-259.

Cook, D. (2002), "Market Entry and International Propagation of Business Cycles", Journal of International Economics, Vol. 56, pp. 155-175.

Cooley, T. (ed), Frontiers of Business Cycle Research, Princeton, 1995.

Darvas, Z., A. Rose, and G. Szapáry (2005), "Fiscal Divergence and Business Cycle Synchronization: Irresponsibility is Idiosyncratic," National Bureau of Economic Research, Working Paper, No. 11580.

Devereux, M., A. Gregory and G. Smith (1992), "Realistic Cross-Country Consumption Correlations in a Two-Country, General Equilibrium Business Cycle Model", Journal of International Money and Finance, Vol. 11, pp. 3-16.

Furceri, D. (2009), "Fiscal Convergence, Business Cycle Volatility and Growth", Review of International Economics, Vol. 17 (3), pp. 615-630, 2009.

Guo, J., and F. Sturzenegger, (1998) "Crazy Explanations of International Business Cycles”, International Economic Review, Vol. 39(1), pp. 111-133.

Hairault, J., (2002) "Labor Market Search and International Business Cycles", Review of Economic Dynamics, Vol. 5(3), pp. 535-558.

Hau, H., (2000) "Exchange Rate Determination: The Role of Factor Price Rigidities and Nontradeables", Journal of International Economics, Vol. 50(2), pp. 421-447. 
Head, A., (2002) "Aggregate Fluctuations with National and International Returns to Scale", International Economic Review, Vol. 43 (4), pp. 1101-1125.

Heathcote, J. and F. Perri (2002), "Financial Autarky and International Business Cycles", Journal of Monetary Economics, 49(3), April, pp. 601-627.

Heathcote, J. and F. Perri (2003), "Why Has the US Economy Become Less Correlated with the Rest of the World?", American Economic Review Papers and Proceedings, May, Vol. 93(2), pp. 63-69.

Heathcote, J. and F. Perri (2004), "Financial Globalization and Real Regionalization", Journal of Economic Theory, Vol. 119(1), pp. 207-43.

Heckman, J. (1999), Trade, Growth and Development, Essays in Honor of Professor T. N. Srinivasan", Ranis and Raut eds.

Kehoe, P. and F. Perri (2002), "International Business Cycles with Endogenous Incomplete Markets", Econometrica, Vol. 70(3), pp. 907-928.

Kollman, R. (1996), "Incomplete Asset Markets and the Cross-Country Consumption Correlation Puzzle", Journal of Economic Dynamics and Control, Vol. 20, pp. 945961.

Kollman, R. (1998), "US Trade Balance Dynamics: The Role of Fiscal Policy and Productivity Shocks and of Financial Market Linkages", Journal of International Money and Finance, Vol. 17, pp. 637-69.

Kollman, R. (2010), "Government Purchases and the Real Exchange Rate", forthcoming in Open Economies Review (special issue 'Testing Open Economy Macro Models').

Lewis, K. (1996), "What Can Explain the Apparent Lack of International Consumption Risk Sharing?", Journal of Political Economy, Vol. 104 (2), April, pp. 267-297.

Pakko, M. (1998), "Characterizing Cross-Country Consumption Correlations", The Review of Economics and Statistics, Vol. 80 (1), pp. 169-174.

Ranis and Raut eds. (1999), Trade, Growth and Development: Essays in Honor of Professor T. N. Srinivasan, North-Holland.

Roche, M. (1996), "Government Spending and the International Business Cycle", Canadian Journal of Economics, Vol. 29(4), pp. 865-884.

Schmitt-Grohé, S. (1998), "The International Transmission of Economic Fluctuations: Effects of U.S. Business Cycles on the Canadian Economy", Journal of International Economics, Vol. 44, pp. 257-287.

Stockman, A., and L. Tesar (1995), "Tastes and Technology in a Two-Country Model of the Business Cycle; Explaining International Comovements", American Economic Review, Vol. 85(1), pp. 168-185.

Tesar, L. (1993), "International Risk Sharing and Non-Traded Goods", Journal of International Economics, Vol. 35, pp. 69-89.

Ubide, A. (1999), "International Transmission of Shocks in a Business Cycle Model Under Imperfect Competition”, Macroeconomic Dynamics, Vol. 3, pp. 341-367. 


\section{Appendix}

\section{The Results of Previous Studies}

Table A-1. International Real Business Cycle Statistics

\begin{tabular}{|c|c|c|c|c|c|}
\hline & $\rho\left(C, C^{*}\right)$ & $\rho\left(Y, Y^{*}\right)$ & $\rho\left(\mathrm{I}, \mathrm{I}^{*}\right)$ & $\rho(L, L *)$ & $\rho(N X / Y, Y)$ \\
\hline Data & 0.3311 & 0.4496 & 0.4151 & 0.2167 & -0.37 \\
\hline Benchmark BKK Model & 0.88 & -0.21 & -0.94 & -0.94 & 0.01 \\
\hline BKK with transport costs & 0.89 & -0.05 & -0.48 & -0.48 & 0.23 \\
\hline Autarky (no risk sharing) & 0.56 & 0.08 & -0.31 & -0.31 & - \\
\hline Tesar (1993) & $\begin{array}{c}\text { Between } 0.44 \\
\text { and } 0.97\end{array}$ & $\begin{array}{c}\text { Between } 0.48 \\
\text { and } 0.7\end{array}$ & - & - & - \\
\hline Baxter $(1995)^{\mathrm{a}}$ & 1 & -0.55 & -0.93 & -0.99 & 0.06 \\
\hline Baxter $(1995)^{b}$ & 0.11 & 0.2 & -0.67 & -0.92 & -0.25 \\
\hline Boileau (1996) & 0.5 & 0.52 & -0.48 & 0.6 & - \\
\hline Kollman $(1996)^{\mathrm{e}}$ & 0.38 & 0.1 & -0.12 & -0.12 & -0.07 \\
\hline Kollman $(1996)^{f}$ & 0.51 & 0.18 & - & - & - \\
\hline Kollman (1996) ${ }^{\mathrm{g}}$ & 0.28 & 0.14 & - & - & - \\
\hline Roche (1996) & 0.78 & -0.07 & - & - & -0.34 \\
\hline Canova and Ubide (1997) ${ }^{\mathrm{d}}$ & 0.72 & 0.78 & 0.27 & 0.8 & -0.32 \\
\hline Guo et al. (1998) & 0.44 & 0.98 & - & - & -0.009 \\
\hline Stockman and Tesar $(1998)^{\mathfrak{c}}$ & 0.26 & 0.5 & - & - & -0.5 \\
\hline Ubide (1999) & 0.73 & 0.26 & -0.15 & 0.32 & -0.55 \\
\hline Heathcote and Perri (2002) & 0.85 & 0.24 & 0.35 & 0.14 & 0 \\
\hline Kehoe and Perri (2002) & 0.29 & 0.25 & 0.33 & 0.23 & 0.27 \\
\hline Cook (2002) & 0.284 & 0.521 & 0.188 & 0.884 & - \\
\hline Hairault (2002) & 0.71 & 0.29 & 0.08 & 0.25 & -0.49 \\
\hline
\end{tabular}


Table A-2. Volatility of the Terms of Trade

\begin{tabular}{|c|c|c|c|c|c|c|c|c|}
\hline & $\begin{array}{l}\text { US } \\
\text { data }\end{array}$ & $\begin{array}{c}\text { Benchmark } \\
\text { BKK } \\
\text { with two } \\
\text { goods }\end{array}$ & $\begin{array}{c}\text { BKK } \\
\text { with two } \\
\text { shocks }^{\text {h }}\end{array}$ & $\begin{array}{l}\text { BKK } \\
\text { with } \\
\text { large } \\
\text { import } \\
\text { share }\end{array}$ & $\begin{array}{c}\text { BKK with } \\
\text { small } \\
\text { elasticity }\end{array}$ & $\begin{array}{l}\text { Ubide } \\
\text { (1999) }\end{array}$ & $\begin{array}{c}\text { Heathcote } \\
\text { and Perri } \\
(2002)\end{array}$ & $\begin{array}{c}\text { Hairault } \\
(2002)\end{array}$ \\
\hline $\begin{array}{l}\text { SD of } \\
\text { TOT } \\
(\%)\end{array}$ & 3.68 & 0.48 & 0.57 & 0.66 & 0.76 & 0.54 & 1.68 & 0.35 \\
\hline
\end{tabular}

Notes: a. Complete markets with no technological spillovers.

b. Incomplete markets and no technological spillovers.

c. With traded and non-traded goods. Shocks to technology and tastes with particular features for taste shocks. Concludes that taste shocks are needed, productivity shocks are not enough.

d. A model with disturbances to both market and household technologies, and financial claims traded internationally.

e. Only debt contracts can be traded in asset markets. Adjustment costs to investment and no cross-country correlation for the productivity shocks.

f. Same as in e with fixed hours.

g. Same as in e with high risk aversion.

h. Both technology and government spending shocks. 